\title{
Clinical \& therapeutical study on inactive ovaries in Holstein-Friesian cows by using GnRH analogues.
}

\author{
T.M. Al-Hamedawi \\ Coll. of Vet. Med. / Unive. \\ of Baghdad
}

\author{
A.S. Al-Ebady \\ Coll. of Vet. Med. /Unive. \\ of Qadissya
}

\author{
O.S. Al-Jubori \\ Coll. of Agri. /Unive. of \\ Baghdad
}

This study was performed on 45 lactating Holstein - Friesian cows suffered from inactive ovaries for three months post partum and diagnosed clinically by rectal palpation in the form of the college of Agriculture / University of Baghdad, their ages 3-5 years during the period from 2010-2012. These cows were divided randomly into 4 groups, $1^{\text {st }}$ group (12 cows) were injected with $0.021 \mathrm{mg}(5 \mathrm{ml})$ Receptal $\mathrm{I} / \mathrm{M}, 2^{\text {nd }}$ group $(12$ cows) were given $500 \mu \mathrm{g}(5 \mathrm{ml})$ Cystorelyin $\mathrm{I} / \mathrm{M}, 3^{\text {rd }}$ group (12 cows) injected with $0.5 \mathrm{mg}(5 \mathrm{ml})$ Fertagil $\mathrm{I} / \mathrm{M}$ in one dose and $4^{\text {th }}$ group $(9$ cows) without treatment (control group). The response rate was 91.8\%, 83.3\%, 91.6\% and 66.6\% for the four groups respectively. While the duration of response (from treatment to oestrus appearance) was $7.43 \pm 1.56,10.66 \pm 2.37,8.44 \pm 2.41$ and $67.63 \pm 9.87$ in the $1^{\text {st }}, 2^{\text {nd }}, 3^{\text {rd }}$ and $4^{\text {th }}$ groups respectively, but the pregnancy rate recorded $90.9 \%, 80 \%, 81.8 \%$ and $83.3 \%$. The statistical analysis showed that the $1^{\text {st }}$ and $3^{\text {rd }}$ group was recorded significant differences higher $(\mathrm{p}<0.01)$ than other groups $\left(2^{\text {nd }}\right.$ and $\left.4^{\text {th }}\right)$ related with responsive animal and the duration of response also but the pregnancy rate recorded higher significance $(\mathrm{p}<0.01)$ compared with $2^{\text {nd }}$, $3 \mathrm{rd}$ and $4^{\text {th }}$ groups. The number of services /conception was more than 1.5-2.5 for all groups \& not significant, the days open recorded higher significant $(\mathrm{p}<0.01)$ in $1^{\text {st }}, 2^{\text {nd }}$ and $3^{\text {rd }}$ compared with $4^{\text {th }}$ group (control group).

\section{Introduction}

The most common causes of the anestrum at the post partum period in cows represented by many reproductive disorders but the inactive ovaries is one of the most important problems which affected on reproductive efficiency in this period $(1,2$ and 3). Many factors affect the interval from parturition to the first estrus and conception at the time of breeding; these include energy balance, high milk production, calf removal and early weaning (4, 5, 6 and 7). Administration of GnRH during the early post partum period has increased early ovulation, but the effect on the interval from calving to conception has been variable $(8,9$ and 10), the LH response produced by $\mathrm{GnRH}$ injection in post partum cows is similar to that seen following its use in cycling cows (11 and 12). GnRH induced ovulation is significantly affected by follicle size and increasing plasma estradiol level at the time of treatment (13 and 14). Maximum life time, production of milk and offspring can be achieved if calving intervals are one year or less (15, 16 and 17).This study presents the post partum anestrum (inactive ovaries) in Holstein - Friesian cows in Iraqi and to investigate the different GnRH analogue treatment upon inactive ovaries.

\section{Materials and Methods}

This study was conducted on 45 lactating Holstein - Friesian cows suffering from inactive ovaries (diagnosed clinically by rectal palpation) in the farm of the college of Agriculture /University of Baghdad. These cows treated with different analogues of $\mathrm{GnRH}$ at day 90 of post partum period according to their parturient dates during the period from 2010-2012, Their ages 3-5 years, these cows were divided randomly into 4 groups, $1^{\text {st }}$ group included 12 cows injected with GnRH analogue 
AL-Qadisiya Journal of Vet.Med.Sci. of $5^{\text {th }}$ conference 21-22 Nov. 2012

Vol. $11 \quad$ No. 3

[Receptal (Intervet B.V.Booxmeer, Holland)] $0.021 \mathrm{mg}(5 \mathrm{ml}) \mathrm{I} / \mathrm{M}$ in one dose at day 90 post partum, $2^{\text {nd }}$ group (12 cows) injected with GnRH analogue [Cystorelyin (CEVA.SANTE-ANIMAL-Spain)] 500 $\mu \mathrm{g}$ (5ml) $\mathrm{I} / \mathrm{M}$ in one dose, $3^{\text {rd }}$ group (12 cows) administered by GnRH analogue [Fertagil (Intervet-International, Holland)] $0.5 \mathrm{mg}$ $(5 \mathrm{ml}) \mathrm{I} / \mathrm{M}$ in one dose also and $4^{\text {th }}$ group (9 cows) without treatment (control group) and 2012 they considered as a control group. The number of responsive animals, duration of response, number of services per conception, number of conceived animals, days open was recorded as well as the nature of parturition, viability and sex of newborn. For analyses of the data used mean, standard error, Chi-square and F-test according to (18).

\section{Results}

The results were showed in table -1represented the type of treatment and response to their treatment, response cows were $91.8 \%, 83.3 \%, 91.5 \%$ and $66.6 \%$ in the $1^{\text {st }}, 2^{\text {nd }}, 3^{\text {rd }}$ and $4^{\text {th }}$ groups respectively. While the duration from treatment till the estrus appearance was $7.43 \pm 1.56$ day, 10.66 \pm 2.37 day, $8.44 \pm 2.41$ day and $67.63 \pm 9.87$ day but the pregnancy rate recorded $90.9 \%, 80 \%, 81.8 \%$ and $83.3 \%$.Table -2- showed the number of services per conception, number of conceived animals and days open. These reproductive parameters were recorded no significant differences $(\mathrm{p}<0.01)$ between all groups about the number of services per conception, while the days open was recorded significant differences $(\mathrm{p}<0.01)$ between the $1^{\text {st }}, 2^{\text {nd }}$ and $3^{\text {rd }}$ compared with $4^{\text {th }}$ group (control group), but the nature of parturition showed that normal parturition recorded $78.1 \%$ compared with $21.9 \%$ represented dystocial parturition (due to many causes) while the sex of calves recorded $56.2 \%$ male and $43.8 \%$ for female, but the viability of calves were $93.7 \%$ for alive calves and $6.3 \%$ for dead calves

Table -1- showed the type of treatment, response animal, duration of response and pregnancy rate.

\begin{tabular}{|c|c|c|c|c|c|c|c|}
\hline Groups & $\begin{array}{l}\text { No. of } \\
\text { animals }\end{array}$ & Type of treatment & $\begin{array}{r}\text { Res } \\
\text { a } \\
\text { No. }\end{array}$ & $\begin{array}{l}\text { ise of } \\
\text { als } \\
\%\end{array}$ & $\begin{array}{c}\text { Duration of } \\
\text { response } \\
\text { (days) }\end{array}$ & \multicolumn{2}{|c|}{$\begin{array}{c}\text { Pregnancy rate } \\
\text { No. } \%\end{array}$} \\
\hline G1 & 12 & $\begin{array}{c}\text { GnRH (Receptal) } \\
0.021 \mathrm{mg}(5 \mathrm{ml}) \\
\mathrm{I} / \mathrm{M}\end{array}$ & 11 & 91.8 & $\begin{array}{c}7.43 \pm 1.56 \\
\mathrm{a}\end{array}$ & 10 & 90.9 \\
\hline $\mathrm{G} 2$ & 12 & $\begin{array}{c}\text { GnRH } \\
\text { (Cystorelyin) } \\
500 \mu \mathrm{g}(5 \mathrm{ml}) \mathrm{I} / \mathrm{M}\end{array}$ & 10 & 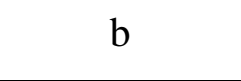 & $\begin{array}{c}10.66 \pm 2.37 \\
b\end{array}$ & 8 & 80 \\
\hline G3 & 12 & $\begin{array}{l}\text { GnRH (Fertagil) } \\
0.5 \mathrm{mg}(5 \mathrm{ml}) \mathrm{I} / \mathrm{M}\end{array}$ & 11 & 91.8 & $\begin{array}{c}8.44 \pm 2.41 \\
\mathrm{a} \\
\end{array}$ & 9 & 81.8 \\
\hline G4 & 9 & $\begin{array}{l}\text { Control group } \\
\text { (without } \\
\text { treatment) }\end{array}$ & 6 & 66.6 & $\begin{array}{c}67.63 \pm 9.87 \\
\mathrm{c}\end{array}$ & 5 & 83.3 \\
\hline
\end{tabular}

*different letters mean significant differences $\mathrm{p}<0.01$. 
AL-Qadisiya Journal of Vet.Med.Sci. of $5^{\text {th }}$ conference 21-22 Nov. 2012

Vol. 11

No. 3

2012

Table -2- showed the number of services /conception, days open and nature of parturition.

\begin{tabular}{|c|c|c|c|c|c|c|c|c|c|c|}
\hline \multirow{2}{*}{$\stackrel{2}{\stackrel{0}{\Xi}}$} & \multirow{2}{*}{ 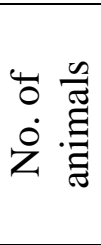 } & \multirow{2}{*}{ 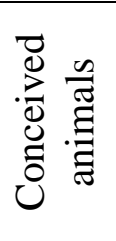 } & \multirow{2}{*}{$\begin{array}{c}\text { No. of } \\
\text { services/ } \\
\text { conception } \\
\mathrm{M} \pm \mathrm{SE}\end{array}$} & \multirow{2}{*}{ 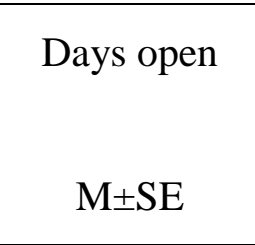 } & \multicolumn{2}{|c|}{$\begin{array}{l}\text { Nature of } \\
\text { parturition }\end{array}$} & \multicolumn{2}{|c|}{ Sex of calves } & \multicolumn{2}{|c|}{ Viability } \\
\hline & & & & & $\mathrm{N}$ & $\mathrm{D}$ & M & $\mathrm{F}$ & $\mathrm{D}$ & A \\
\hline 1 & 12 & 10 & $2.02 \pm 0.41 \mathrm{a}$ & $134.36 \pm 8.27 \mathrm{a}$ & 7 & 3 & 6 & 4 & 9 & 1 \\
\hline 2 & 12 & 8 & $1.98 \pm 0.62 \mathrm{a}$ & $137.35 \pm 9.15 \mathrm{a}$ & 7 & 1 & 4 & 4 & 7 & 1 \\
\hline 3 & 12 & 9 & $2.13 \pm 0.43 a$ & $136.85 \pm 7.42 \mathrm{a}$ & 7 & 2 & 5 & 4 & 9 & 0 \\
\hline 4 & 9 & 5 & $2.23 \pm 0.13 \mathrm{a}$ & $196.63 \pm 8.26 b$ & 4 & 1 & 3 & 2 & 5 & 0 \\
\hline 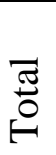 & 45 & 32 & ------------ & & & & $\begin{array}{r}18 \\
56.2\end{array}$ & $\begin{array}{c}14 \\
3.8 \%\end{array}$ & $\begin{array}{r}30 \\
93.7\end{array}$ & $\begin{array}{c}2 \\
5.3 \%\end{array}$ \\
\hline
\end{tabular}

*different letters mean significant differences $\mathrm{p}<0.01$.

$\mathrm{N}=$ normal, $\mathrm{D}=$ Dystocia, $\mathrm{M}=$ male, $\mathrm{F}=$ female, $\mathrm{D}=$ dead, $\mathrm{A}=$ alive.

\section{Results}

The results were showed in table -1represented the type of treatment and response to the treatment, response cows were $91.8 \%, 83.3 \%, 91.5 \%$ and $66.6 \%$ in the $1^{\text {st }}, 2^{\text {nd }}, 3^{\text {rd }}$ and $4^{\text {th }}$ groups respectively, while the duration from treatment tills the estrus appearance was $7.43 \pm 1.56$ days, 10.66 \pm 2.37 days, $8.44 \pm 2.41$ days and $67.63 \pm 9.87$ days but the pregnancy rate recorded $90.9 \%, 80 \%, 81.8 \%$ and $83.3 \%$. Table -2- showed the number of services per conception, number of conceived animals and days open, these reproductive parameters were recorded no significant differences $(\mathrm{p}<0.01)$ between all groups about the number of services per conception while the days open was recorded significant differences $(p<0.01)$ between the $1^{\text {st }}, 2^{\text {nd }}$ and $3^{\text {rd }}$ compared with $4^{\text {th }}$ group (control group ), but the nature of parturition showed that normal parturition recorded $78.1 \%$ compared with $21.9 \%$ represented dystocial parturition (due to many causes ) while the sex of calves recorded $56.2 \%$ male and $43.8 \%$ for female, the viability of calves were $93.7 \%$ for alive calves and $6.3 \%$ for dead calves.
The results revealed that the responsive animals and duration of response in $1^{\text {st }}$ and $3^{\text {rd }}$ group were recorded superior significant differences $(\mathrm{p}<0.01)$ compared with $2^{\text {nd }}$ and $4^{\text {th }}$ group, also the $2^{\text {nd }}$ group recorded higher significant differences $(\mathrm{p}<0.01)$ with $4^{\text {th }}$ group (control group) $(3,4$, 5 and 8), this results agreement with $6,9,11$ and 13 . The pregnancy rate was significantly higher $(\mathrm{p}<0.01)$ in $1^{\text {st }}$ group compared with $2^{\text {nd }}, 3^{\text {rd }}$ and $4^{\text {th }}$ groups ( 4 and 9). There are no significant differences between all groups related with the number of services per conception (14), while the days open was recorded superior significant differences

\section{Discussion}

$(\mathrm{p}<0.01)$ between $1^{\text {st }}, 2^{\text {nd }}$ and $3^{\text {rd }}$ group compared with $4^{\text {th }}$ group, these results agree with 10, 11, 13 and reported by many authors $(6,8,16$ and 17) and these results which explain the role of hormonal treatments for improving the reproductive parameters. The dystocial parturitions rate were recorded $21.9 \%$ in all groups as well as they recorded $93.7 \%$ which represented a live newborn and $6.3 \%$ for dead $(13,15$ and 16).It was concluded that the using of hormonal regimes in post partum which indicated to reduce the reproductive problems especially inactive ovaries. 


\section{References}

1. Roche, J.F.; Crow, M.A. and Boland, M.B. (1991). Post- partum anestrous in dairy and beef cows. Anim. Reprod. Scien. 28: 371-378.

2. Beam, S.W. and Butler, W.R. (1999). Effects of energy balance, follicular development and first ovulation in post partum dairy cows. J. Reprod. Fertil. 54 (suppl): 411-424.

3. Robert, S.Y. and Walter, R.T. (2007). Large animal Theriogenology $2^{\text {nd }}$ ed. Saunders, an imprint of Elsevier ING. Pp: 616, 723, 1212-1224.

4. Arthington, J.D. and Kalmbacher, R.S. (2003). Effect of early weaning on the performance of three years old, first - calf beef heifers and calves reared in the sub stropic. J. of Anim. Sci. 81: 1136-1141.

5. Arthington, J.D. and Minton, J.E. (2004). The effect of early weaning on feed intake, growth and post partum interval in thin Brahman crossbred primiparous cows. Prof. Anim. Sci. 20: 34-38.

6. Mwaanga, E.S. and Janowski, T.(2000). Anoestrous in dairy cows: causes, prevalence clinical form. Reprod. Dom. Anim. 35: 193-200.

7. Wiltbank, M.C. (2005). Relationship between level of milk production and multiple ovulations in lactation dairy cows. J. of Dairy Sci. 88: 2783-2793.

8. Stevenson, J.S. and Call, E.P. (1988). Fertility of post partum dairy cows after administration of gonadotropine - releasing hormone and PGF2 $\infty$ : A field trial. J. of Dairy Sci. 71: 1926-1933.

9. Archbald, L.F.S.; Norman, E.L.; Bliss, T.; Tran, S.; Lyle, P.G.; Thomas, G. and Rath well, A.C. (1990). Incidence and treatment of abnormal post partum ovarian function in dairy cows. Theriogenology: 34: 283-290.
10. Foot, R.H. and Rick, P.M. (1999). Gonadotropine - releasing hormone improves reproductive performance of dairy cows with slow involution of the reproductive tract. J. Anim. Sci. 77: 12-16.

11. Kesler, D.J.; GarvericK, H.A.; youquest, R.S.; Elmore, R.G. and Bierwal, C.J. (1977). Ovarian and endocrine response and reproductive performance follicular GnRH induced L.H. release in dairy cows. J. of Anim. Sci. 46: 797-803.

12. Devries, A.; Crane, M.B. and Melendez, C.A. (2008). Management and treatment of dairy cows that are not cycling or have follicular cyst. J. Anim. Sci. (21): 226.

13. Hyder, A.U. and Utlah, S. (2002). Effects of month and year of calving on 305 days milk yield in Holstein Friesians: in tropical conditions. Ind. J. Dairy Sci. 49 (8): 525-529.

14. Mwaanga, E.S.; Zdunczyk, S. and Janowski, T. (2004). Comparative study on the non hormonal treatment methods in ovarian function affected dairy cows. Bull. Vet. Inst. Pulway 48: 265-267.

15. Rafique, M.M.R.; Chohan, B. and Chaudhry, Q.Z. (2000). Reproductive performance of inter Sc. Holstein - Friesian x Schiwal crossbred. Pakistan vet. J. 20(3): 109-112.

16. Sattar, A.; Mirza, R.H.; Niazi, A.A.K. and Latif, M. (2005). Productive and reproductive performance of Holstein - Friesian cows in Pakistan. Pakistan vet. J. 25 (2): 75 81.

17. Thomas, R. and Rathwell, A.C. (1990). Incidence and treatment of abnormal post partum ovarian 
AL-Qadisiya Journal of Vet.Med.Sci. of $5^{\text {th }}$ conference 21-22 Nov. 2012 Vol. 11

function in dairy cows.

Theriogenology: 34: 283-290.
No. 3

statistics. Mc. Grow. Inc. New York, U.S.A.

18. Steel, R.D.G. and Torrie, J.H. (1984).

Principles and procedures of

\section{دراسة سريرية وعلاجية لحالة خمول المبايض في ابقار الهولشتاين - فريزيان

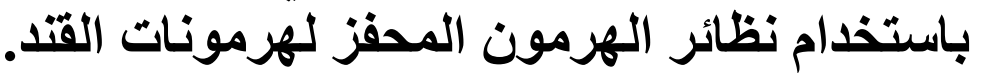

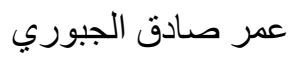

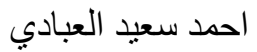 \\ طالب موسى عبداله الحميداوي \\ كلية الزر اعة /جامعة بغداد \\ كلية الطب البيطري / جامعة القادية العبادية \\ الخلاصة}

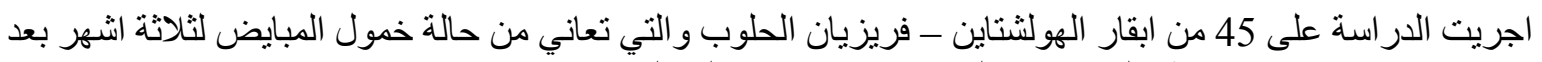

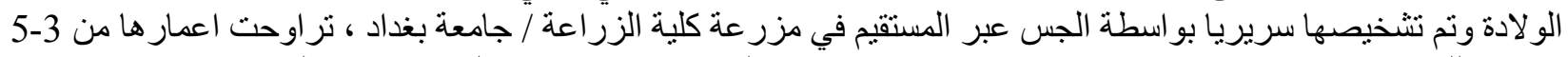

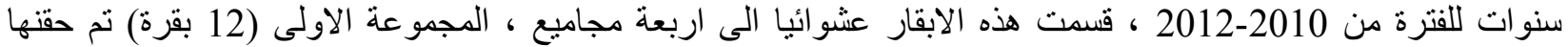

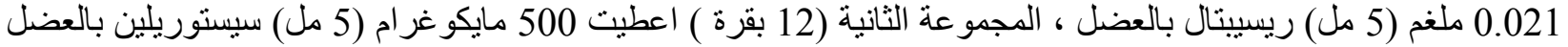

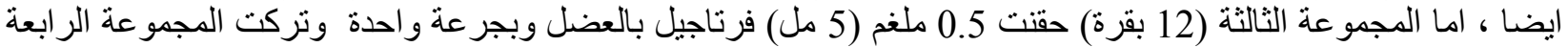

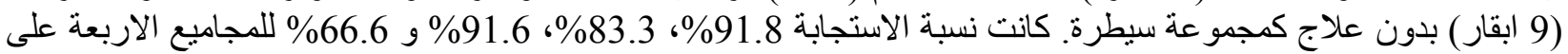

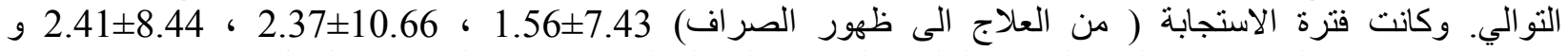

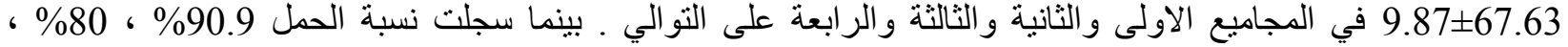

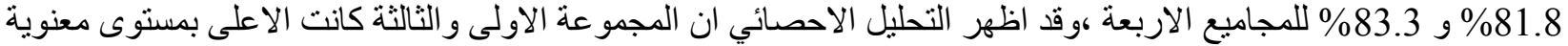

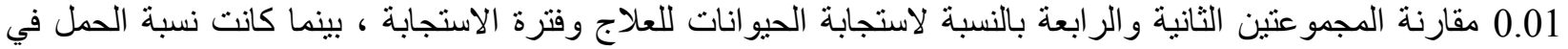

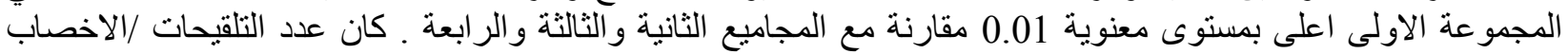

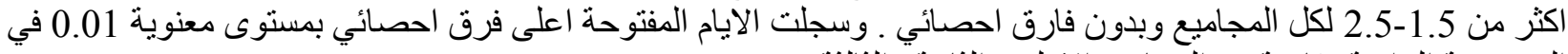

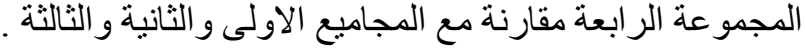

